\title{
Competence modules of the agro-environmental engineering bachelor course in Hungary
}

\author{
Csaba Juhász, Julianna Mocsáriné Fricz \\ University of Debrecen Centre for Agricultural Science and Engineering Faculty of Agriculture and Food Sciences and \\ Environmental Management
}

Keywords: competency, competence profile

\begin{abstract}
One of the most important goals of the Bologna Process is to introduce the three circle system: bachelor, master, doctorate courses. In Hungary from 2006/2007 academic year 132 bachelor courses are launched. One of the launched bachelor course is environmental engineering of which the scientific background and economical sector are rapidly changing. Hence, to help graduates from this area to find a job, it is very important to examine working activities, expectations of employers, to study requirements of the training programs, the system of competencies. Having examined these points, frameworks of professional requirements have been worked out by 27 validation tests. In this publication, the results of the research work related to the environmental engineering bachelor program were presented.
\end{abstract}

\section{Introduction}

Geopolitical changes of last decade, difficulties of managing of information-flow, deepening ecological crisis or financial suspense in private life are problems either for the society or for the person. To solve them, adults couldn't be provided for by school. Through the quick technological development, the role of the work based on knowledge has increased. Hence, the rate of graduates has been growing.

Hungarian higher education can be characterized by the process of quick and sometimes radical changes. In Hungary, higher education fills more and more important function in the society, it is one of the engines of the economic development, the turning point of life long learning. Higher education institutions have to prepare an efficient and successful employee for the labour market. However, it is not only "to bard" the employee with knowledge, according to requirements of workplace, but higher education institutions have to train experts with professional knowledge and logical mind, acquainted with problems of their speciality. Investment in education has cleared in economy, not only by money, but by human quality, living standard and living quality.

The overarching aim of the Bologna Process is to create a European Higher Education Area (EHEA) by 2010. The Bologna Process is based on international cooperation and academic exchange. These are attractive to European students and staff as well as to students and staff from other parts of the world, mostly from the United States of America and Asian countries.

The three priorities of the Bologna Process are: introduction of the three cycle system: bachelor, master, doctorate courses; quality assurance and recognition of qualifications and periods of study. Every second year the ministers of higher education have met to measure progress and set priorities for action.

In the linear educational system that is realized on the subject of the Bologna Process, qualifications have to be exactly comparable and acceptable throughout Europe. The EHEA will facilitate mobility, it will make European citizens to find a job and to continue their education even abroad. This system can help students, researchers, graduates to make international scientific contacts.

The EHEA will prepare students for their future careers and for life as active citizens in democratic societies. The Bologna Process unites countries. All across Europe, countries and universities are 
engaged in this process of modernisation. These countries take part in the European Cultural Convention and committed to the goals of the EHEA. More than 5600 universities and about 31 million students have been touched by the reform. An important characteristic of the Bologna Process and key to its success, is that it also involves European Commission and Council of Europe, as well as representatives of higher education institutions, students, staff and employers.

Through the Bologna Process, in forming their trainings, higher education institutions have to endeavour to meet requirements of labour market. It is needed to have a successful employee graduated from a training system based on knowledge and experience at workplace. For the developing of manufacturer and supplier sphere, employee with rich competence supply is requisite. Nowadays, employers expect from applicant to have some important competencies, instead of graduation.

\section{MATERIAL AND METHOD}

Definition of competency is a set of observable performance dimensions of a person, including individual knowledge, skills, attitudes and behaviours. As well as collective team, process and organizational capabilities facilitate the successful accomplishment of a given task. To develop someone's competency, it is relevant to capacitate him or her to act in an environment where the need for certain, specific activities is unknown at present. To define and examine somebody's competences and competences required by labour market, it is essential to compose some criteria to set up a competence profile.

A competence can be considered profession specific if:

- it is essential for fulfilling a main profession task,

- its state of development highly influences the success and performance of the professional.

Because of the above mentioned criteria, profession specific competencies can be considered key professional competencies.

In key professional competencies there are three different groups:

- personal competencies with aptitude and characteristic competence groups

- interpersonal competencies with cooperation, communication and conflict handling competence groups

methodological competencies with thinking, problem-solving and work style competence groups.

In labour market, requirements set to employee can be examined as competence to solve defined tasks. Therefore it is crucial to regard analysis of working activities and personal characteristics as basic documents. Connection between somebody's knowledge, competence, personal characteristics and requirements of a profession will be comprehensible even for people without knowing a profession. Hence to plan a career can be easier. Life long learning means to participate in trainings in higher education institutions. At the same time life long learning can be defined by development of new competences, acquisition of specific knowledge of a profession and other personal activities.

Competencies have a very important role in planning programs of higher education institutions and in labour market also. To help a graduate to find a job right after having his degree, it is essential that the training institutions and employers have to be in a continuous touch with each other, to exchange their experiences.

The competence profile consists of a work task profile and an attribute or feature profile. Professional requirements of a qualification define the expected competencies of an employee. In this context competencies mean the suitability and capability of performing a work task. In detail, it covers the work tasks as a manifestation of work activity, on the other hand it appears as the attributes of the employee as prerequisites of the work activity. Therefore a competency profile of a qualification comprises of two projections of the person's standard competence set, the work task profile and the 
attribute profile. The work task profile is the ordered listing of those work tasks, which can be performed by an employee based on his or her qualification.

The attribute profile describes the capability of a person for completing work activities corresponding to his or her qualification, namely professional knowledge and skills in the system of attributes characterizing the person. The attribute profile contains those competencies, which can be attained during training and practical work, and needed predominantly after receiving a qualification and consequently holding a position.

The categories of the attribute profile are the following:

professional competencies

personal competencies

social competencies

methodological competencies

As part of the attribute profile, professional competencies contain professional requirements of the qualification, which are exclusively applied in the course of a work activity. Knowledge directly applied during work can include among others:

the sequence of procedures, technological regulations,

complex use of instruments and sources,

the applied numeric parameters and quantitative features,

the use of regularly occurring decisive data and information during work,

data and information related to the behaviour of materials, objects, tools, instruments applied in the procedures,

data and information related to the conditions and effects of the work as well as risks and consequences of deviation from work instructions and safety regulations, etc.

Apart from professional knowledge, professional skills are components, elements or actions operating automatically, without direct control of the senses. Skills are usually less complex actions or smaller elements of actions. They generally develop as a result of longer processes such as studying and practice.

Professional specific methodological-, social-, interpersonal- and personal competencies are those, which are essential for the successful completion of professional tasks.

\section{RESULTS AND DISCUSSION}

In this publication, we have analyzed expected competencies of graduates from the agri-environmental engineering bachelor program. These competencies have been defined in training requirements of the programs. According to these expectations, accreditation documents have been prepared. Having them accepted, in 2006/2007 semester bachelor programs were launched. It can be determined that demands of competencies defined 3 or 4 years ago, they can't be reckoned as stable, constant requests, in consideration of permanent economic, technological development and innovation. It is needed to review the training programs.

In the course of the survey presented in the publication, a questionnaire of 49 questions was sent to the employers attending agro-environmental engineers, nature protection engineers. Altogether 89 employers filled questionnaires, they can be considered as potential employers of the graduates from the two bachelor programs. Through their answers, it is needed to know their activity; number of their employees; according their activity that is connected to environmental protection, we have analyzed their knowledge about training contents of the bachelor program; their requirements in reference to employees' competencies; their aim to contribute in developing training programs. In analyzing, our purpose was to get acquainted with human resource demands of labour market, in particular in the case of graduates of the bachelor program. For the sake of the cause, we looked up firms either in environmental, nature protection, or in agriculture.

Besides of sending questionnaires to employers, we have gathered samples of documentations of working activities, then we have evaluated them. Letters measuring employers' demand, have been sent in order to be informed graduated with agro-environmental engineering and nature protection 
engineering degree could be accepted to what kind of work places. By answers employers' training requirements can be analysed.

The investigation of competencies required by the economy was made by tests of 50 questions. Compiling the test, it was very important to make it simple for employers to fill, to build in some specific questions. Tests were sent to 75 companies, altogether. Most of the companies deals with environmental protection, least of them are agricultural companies. The returned tests were analysed by SPSS, from which some diagrams were made.

The tests were sent to 75 companies. From 75 companies, 36 returned the filled tests. From the tests, we can determine that mainly authorities $(21 \%)$ and economic organizations (18\%) answered our questions. The centre of these companies is situated in West Hungary. Most of the inquired ones have known about the Environmental Engineering bachelor course, they are working in an agricultural field. More over they have employees with graduation from the field of agricultural science. They think that, in spite of the fact that on the whole the economy has know little about the Bologna Process and the transformation of the higher educational system, it is not more difficult for a graduate with a degree of Environmental Engineering to have a job than with other kind of degree (Figure 1).

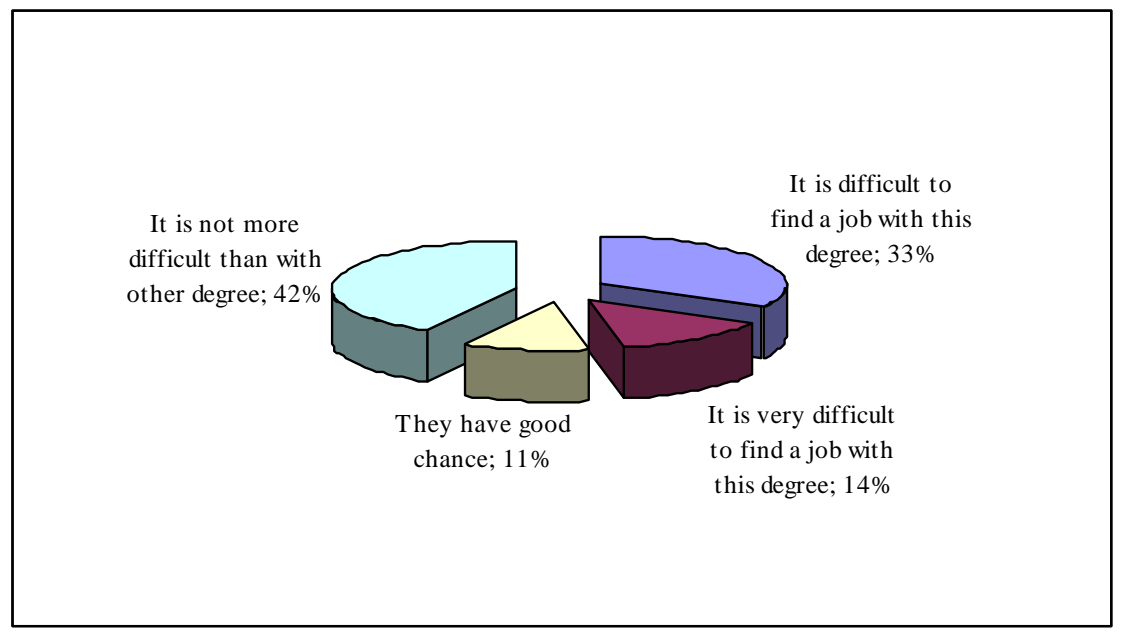

Figure 1.

\section{Employers' opinion about the value of the Environmental engineering degree at labour market}

Examining the general knowledge and skills that is important to have when a graduate looks for a proper job, computer technics are the most necessary and the least is type-writing.

To have some practice in the field where the company is effective, is not so needed condition. They think that it can be acquired during work. From the tests, it is a significant point that companies are opened to work out theoretical and practical training with the higher education institutions. They are interested in most of the training types. According to the practical training, $80 \%$ of the respondent companies have already accepted students for summer practice. Hence, they have some experiences. Three-quarter of the respondents would encourage employees with vocational training or bachelor degree to learn more and to have bachelor or master degree.

$38 \%$ of the responding companies would employ graduates with Environmental Engineering degree.

In the bachelor course of the Environmental Engineering, students can choose three specializations. In the economy amongst these specializations, the settlement development and the environment protection are the most interested, the quarter of the asked companies is motivated by waste management specialization. 
Examining the general field of knowledge, these are financial, marketing, legal, economical ones that are very relevant for a young people to have when he applies for a job. Naturally, professional knowledge of environmental protection is firstly required at these companies.

In the tests we have drawn some proper questions about knowledge needed at companies. This was a very interesting examination. Analysing the returned and filled tests, we have tried to use the opinion of the participants of the labour market and to build it in our curriculum.

We have reviewed competencies of the training requirement of the course and we have reformed them to be accordant with the expectations of the participants of the labour market and of course, with the goals of the higher education institution, with the prerequisites of the science of environmental protection.

To be successful in this work, it were not only the tests to examine, but also descriptions of working activities and training requirements of the course.

The labour market developing very fast, we mustn't stop to review the curriculum. If we liked to have a competitive course that was suitable to the new challenges of the science, we have to re-examine our results in every third year. In every third year, because the bachelor courses have three year to learn.

Results of these analyses have been compared to competences written in training requirements of bachelor program. Synthesis of modules of the bachelor programs has been determined. The work task profiles have been valued by experts of labour market. The valuation has been done electronically by means of validation tables. 27 validation tests for the agri- environmental program have been worked out by means of SPSS. In the course of the validation, competencies of the modules have been qualified by experts in a scale. The validation has been done in all modules, in work task profile by a validation table (Table 1).

Table of validation

\begin{tabular}{|c|c|c|c|c|c|c|c|c|c|c|c|c|c|c|c|c|c|}
\hline \multirow{3}{*}{ Work task profile } & \multicolumn{6}{|c|}{ Importance of the task } & \multicolumn{6}{|c|}{ Frequency of task } & \multicolumn{5}{|c|}{ Difficulty of task } \\
\hline & $\begin{array}{l}\stackrel{\text { 으 }}{\widetilde{N}} \\
\stackrel{\text { I }}{ }\end{array}$ & 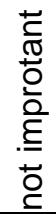 & & & & 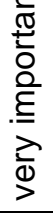 & $\begin{array}{l}\bar{\Phi} \\
\grave{\Phi}\end{array}$ & $\begin{array}{l}\varepsilon \\
\frac{\varepsilon}{0} \\
\frac{0}{2} \\
\mathscr{c}\end{array}$ & 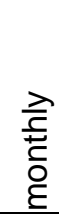 & $\begin{array}{l}\vec{\lambda} \\
\frac{\vec{v}}{\Phi} \\
\stackrel{0}{3}\end{array}$ & 름 & 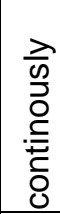 & $\frac{\frac{0}{0}}{\frac{\frac{1}{\omega}}{\omega}}$ & & & & 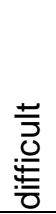 \\
\hline & & 1 & 2 & 3 & 4 & 5 & & & & & & & 1 & 2 & 3 & 4 & 5 \\
\hline
\end{tabular}

Table 1.

The first round of questions was about how important the task was without reference to whether the evaluating person did the task. In the next round of questions, it was examined the frequency of a task fulfilling and then its complexity. At the end of this examination, counting the average of the importance, the frequency and the complexity was valued. As results, competencies said to be relevant by the experts of labour market and experts of higher education can be excepted.

Evaluation based on competency has gathered more and more ground and become a determinative notion for the sake of the higher education training system transformed by the Bologna process. Since the launch of bachelor programs in Hungary, we have to declare that requirements according to competencies, determined before the launching of the first bachelor courses in Hungary - as the agroenvironmental engineering bachelor course -, can't be considered as constant, stable expectations because of economic, technologic, innovation changes. Hence, these requirements have to be reanalysed in order to run a competitive training system.

It is very important for higher education institutions to be in touch with employers. In order to support to achieve this goal, in the questionnaire we have asked employers whether they are willing to cooperate with higher education institutions in terms of either theoretical, practical training or even both (Figure 2). 


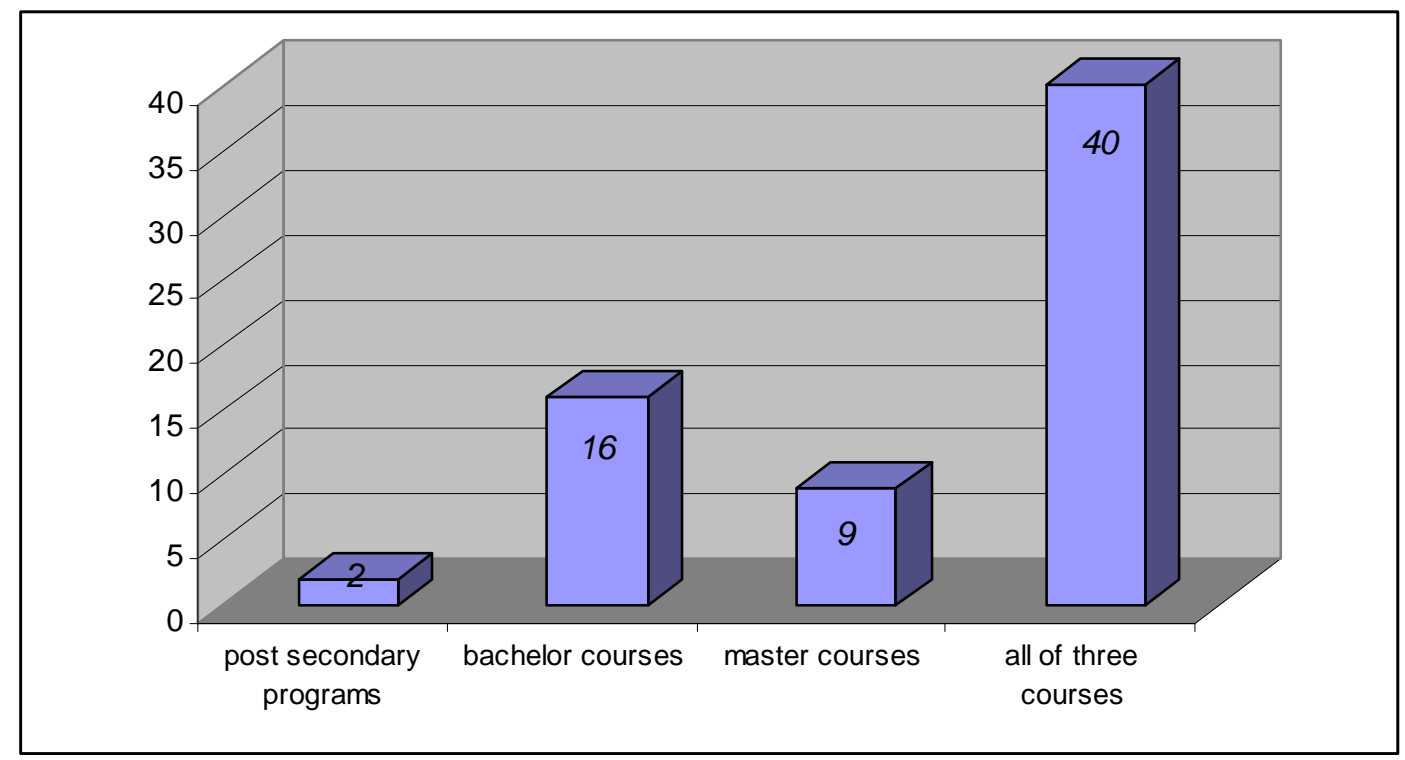

Figure 2.

Employers' answers about the object of the cooperation with the higher education institution

Analysing the answers of the questionnaire, employers declared they were ready to cooperate with higher education institutions in case of survey of theoretical and practical training. According to practical training, we have also examined the way of the cooperation (Figure 5). According to answers, employers have inclined in for example advertising, helping practical training as practical site.

The basic function of a qualification is when a graduated person is employed, the person's skills and competencies should be known by the employer just by concluding working contract, creating list of working activities, determining working tasks. Besides the school report of qualification, the employer can be informed about the employee's knowledge, skills, capability and competencies from other source like in which institution the employee passed exams, references of his former working place, being on probation, the employee's competencies can be observed.

Concerning to vocational training, the definition of module can be interpreted in different ways. In this research modules have been formed of competencies that were told to be equal in compared vocational trainings. Training system based on modules is a requirement system without reference to training process that has been separated from each other. To understand professional requirement modules of Agro-environmental engineering bachelor course, it needs to know modules of post secondary program on waste management.

Work task profiles contain tasks that are required in labour market. Attribute profiles have properties that are possessed to make somebody be able to accomplish a professional task. The competence module of this post secondary program has 5 professional modules (Figure 3): 2288-06: Basic knowledge, 2293-06: Tasks of waste management, 2294-06: Tasks of communal waste management, 2295-06: Tasks of agricultural waste management, 2296-06: Tasks of victualing waste management. 


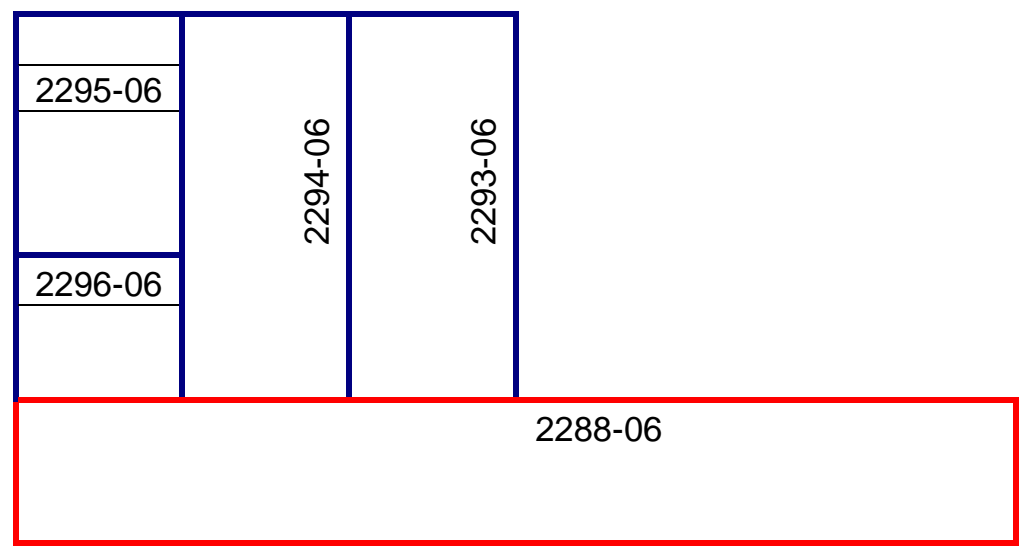

Module map of post secondary program on waste management

Figure 3.

The competence module of agro-environmental engineering bachelor program has 6 professional modules (Figure 4): DE OKJ 2288-06: Basic knowledge, DEHG-KG OKJ 2293-06: Tasks of waste management, DEHG-KG OKJ 2294-06: Tasks of communal waste management, DEHG-KG 22952296-06: Tasks of agro-environmental and victualing waste management, DEKG 32-08: Tasks of environmental management. At the same time, this is the total module map of the post secondary and the bachelor programs.

\section{CONCLUSION}

In labour market, requirements set to employee can be examined as competence to solve defined tasks. Therefore it is crucial to regard analysis of working activities and personal characteristics as basic documents. Connection between somebody's knowledge, competence, personal characteristics and requirements of a profession will be comprehensible even for people without knowing a profession. Hence to plan a career can be easier.

Life long learning means to participate in trainings in higher education institutions. At the same time life long learning can be defined by development of new competences, acquisition of specific knowledge of a profession and other personal activities.

Competencies have a very important role in planning programs of higher education institutions and in labour market also. To help a graduate to find a job right after having his degree, it is essential that the training institutions and employers have to be in a continuous touch with each other, to exchange their experiences.

The research presented in this publication can be helpful for students in getting acquainted with requirements of training programs and labour market, it can also be relevant in life long learning. For professors by this research work development of curriculums can be optimized. Higher education institutions can make their training programs acceptable by labour market in order to provide graduates to find a good job. At the same time, employers are aware of graduates' competencies. They can apply them at suitable workplaces, which can be the basic of the future success of the enterprise. 


\section{References}

Juhász Cs (2008): A környezetgazdálkodási agrármérnök és természetvédelmi mérnök BSc alapképzések kompetenciáinak tartalmi értékelése és fejlesztése In: Korszerü mérnöki tudással a környezetért Zárókonferencia kiadvány, Debrecen

Henczi L. - Zöllei K.(2007): Kompetenciamenedzsment, Perfekt Kiadó, Budapest

Hrubos I..(2002): A Bolognai folyamat Európai trendek A Bolognai Nyilatkozatból adódó strukturális változások megvalósíthatósága a magyar felsőoktatásban, Oktatáskutató Intézet, Budapest Szerk: Czeizer Zoltán

Polónyi, I. - Tímár, J. (2001): Tudásgyár vagy papírgyár. Új Mandátum Könyvkiadó. Budapest

Tamás J. (2008): Újabb tankönyvek a Környezetgazdálkodási agrármérnök képzés szolgálatában (In: Kátai J. (szerk.): Korszerü mérnöki tudással a környezetért), Debrecen 